\title{
Çalışan Kadınlarda Evlilik Doyumunun Yordayıcısı Olarak Kişiler Arası Yeterlilik ve İş-Aile Çatışmasını Yönetme Öz Yetkinliği*
}

Gülnar Habibova Doğan ${ }^{1}$ ve Nursel Topkaya ${ }^{2 * *}$

Öz

Anahtar Sözcükler

$\mathrm{Bu}$ araştırmanın amacı, evli ve çalışan kadınlarda evlilik doyumunun yordayıcısı olarak kişiler arası yeterlilik ve iş-aile çatışmasını yönetme öz yetkinliği düzeylerini incelemektir. Araştırmanın çalışma grubunu Ankara, Malatya, Samsun ve Kastamonu illerinde farklı kurum ve kuruluşlarda çalışan 515 kadın oluşturmuştur. Katılımcılara Kişiler arası Yeterlilik Ölçeği, İş-Aile Çatışmasını Yönetme Öz-yeterliği Ölçeği, Evlilik Doyum Ölçeği ve Demografik Bilgi Formu uygulanmıştır. Araștırma verilerinin analizi SPSS 23 istatistik programında gerçekleştirilmiştir. Araştırma sonucunda evlilik doyumu puanlarının öğrenim düzeyi ve aylık gelir ile düşük düzeyde pozitif yönde ilişkili olduğu; evlilik süresi, evlilik biçimi ve çocuk sayısı değişkenleriyle evlilik doyumu puanlarının düşük düzeyde negatif yönde ilişkili olduğu kişilerin evlilik sayısı, eşleri ile aralarındaki yaş farkı ve evlenme yaşları ile evlilik doyumu ise ilişkil değildir. Ayrıca, kişiler arası yeterlilik ve iş-aile çatıșmasını yönetme öz yetkinliğinin sosyo-demografik değişkenlerin etkisi kontrol edildiğinde evlilik doyumundaki değişimlerin yaklaşık olarak \% 7'sini yordadığı bulunmuştur. Elde edilen sonuçlar ilgili literatür kapsamında tartışılmıştır.

Evlilik doyumu Kişiler arası yeterlilik İş-aile çatış̧asını yönetme öz yetkinliği

Makale Hakkında

Gönderim Tarihi 03 Eylül 2020

Kabul Tarihi

26 Kasım 2020

Makale Türü

Araştırma Makalesi

DOI: $10.12984 /$ egeefd. 790218

\section{Interpersonal Competence and Work-Family Conflicts Self-Efficacy as Predictors of Marriage Satisfaction among Working Women*}

\section{Abstract}

The purpose of this study was to investigate interpersonal competence and work-family conflicts selfefficacy as predictors of marriage satisfaction among working women. Participants consisted of 515 married women who residing in Ankara, Malatya, Samsun and Kastamonu and working in various institutions and organizations. Researchers administered the Interpersonal Competency Scale (ICS), the Work-Family Conflict Self-Efficacy Scale (WFCSES), Marriage Satisfaction Scale (MSS), and the Demographic Information Form developed by the researchers. As a result of the study, researchers found that marriage satisfaction scores were positively correlated with education level and monthly income; marital satisfaction scores were negatively correlated with duration of marriage, type of marriage, and number of children. It was found that there was no relationship between marriage number, age difference between their spouses, marriage age and marriage satisfaction. Moreover, the results demonstrated that interpersonal competence and self-efficacy in managing work-family conflict predicted an additional $7 \%$ of variance in marital satisfaction. The findings were discussed in relation with the existing literature.
Keywords

Marital satisfaction

Interpersonal

competence

Self-efficacy of

managing work-family conflict

Article Info

Received

September 03, 2020

Accepted

November 26, 2020

Article Type

Research Paper

Atıf: Habibova Doğan, G. ve Topkaya, N. (2020). Çalışan kadınlarda evlilik doyumunun yordayıcısı olarak kişiler arası yeterlilik ve iş-aile çatışmasını yönetme öz yetkinliği. Ege Eğitim Dergisi, 21(2), 76-90. doi: 10.12984/egeefd.790218

\footnotetext{
* Bu çalışma, Gülnar Habibova Doğan tarafından Doç. Dr. Nursel Topkaya danışmanlığında hazırlanan yüksek lisans tezinden üretilmiştir.

[This study was produced from master thesis prepared by Gülnar Doğan under the supervision of Assoc. Prof. Dr. Nursel Topkaya.]

1 (1) Ondokuz Mayıs Üniversitesi, Eğitim Fakültesi, Eğitim Bilimleri Bölümü, Rehberlik ve Psikolojik Danışmanlık Anabilim Dalı, Türkiye, gulnar.habibi@gmail.com

2 (1) Ondokuz Mayıs Üniversitesi, Eğitim Fakültesi, Eğitim Bilimleri Bölümü, Rehberlik ve Psikolojik Danışmanlık Anabilim Dalı, Türkiye, nursel.topkaya@omu.edu.tr
} 


\section{Extended Abstract}

\section{Introduction}

Numerous studies demonstrate that many factors affect the quality of a marriage and marital satisfaction of spouses. For instance, sociodemographic characteristics were found to be related to marital satisfaction. Apart from socio-demographic characteristics, it is believed that a variable that may be related to marital satisfaction may be interpersonal competence. Because interpersonal competence includes a number of interpersonal skills, which can be described as the sum of the social skills of individuals, starting relationships or rejecting unreasonable requests, emotional support and conflict management (Şahin \& Gizir, 2013). Researchers state that individuals lacking interpersonal competence consisting of basic cognitive components such as knowledge, skills, and motivational structures may be inadequate in establishing and maintaining close relationships (Şahin \& Gizir, 2013).

Due to the roles of the working women, they can experience job and family conflicts and this may decrease their satisfaction with the marriage. However, when the literature is examined, it is seen that studies related to workfamily conflict are carried out with demographic factors rather than psychological qualities (Amanvermez \& Denizli, 2016). However, the evaluations and psychological characteristics of the individuals about themselves are also an important variable in dealing with work-family conflict and reducing their negative effects (Amanvermez \& Denizli, 2016). In this context, the self-efficacy of women working as a psychological variable in managing work-family conflict may also be a variable that may affect marital satisfaction. Accordingly, the purpose of this study is to examine the sociodemographic variables related to marital satisfaction in working women firstly and to examine the interpersonal competence and self-efficacy in managing interpersonal competence and work-family conflict after controlling the effect of the associated sociodemographic variables.

\section{Method}

This research is a correlational study examining interpersonal competence and self-efficacy to manage workfamily conflict as predictors of marital satisfaction in working women participants of the study consisted of 515 working women working in various institutions and organizations in located in Ankara, Malatya, Samsun, and Kastamonu provinces and were reached through convenience sampling. The age range of the women constituting the study group of the study varied from 20 to 62 , and the average age was $38.31(S D=8.23)$. The Interpersonal Competence Scale, Managing Work-Family Conflict Self-Efficacy Scale, Marital Satisfaction Scale, and Demographic Information Form were administered to the participants. Before the analyses were performed, the assumptions of normality, linearity, normality of regression errors, homoscedasticity were examined and met (Hair, Black, Babin, \& Anderson, 2014; Tabachnick \& Fidell, 2012). The significance level was accepted as $p<$ .05 in all analysis.

\section{Findings}

When the marital satisfaction of the participants was evaluated as a whole (mean $=7.63$ ), it was found to be high, the average marriage age was $24.79(S D=4.86)$, with an average of 1.44 children $(S D=.99)$, their interpersonal competence levels were moderate and their ability to manage work-family conflict was at moderate level.

The sociodemographic variables associated with marital satisfaction entered in the regression equation in the first stage explained approximately $5 \%$ of the change in marital adjustment scores and this change was significant $(F$ $\left.(5,509)=5.67, \Delta R^{2}=.05, p<.001\right)$. In the second stage, the interpersonal competence and self-efficacy scores of managing family conflict, which were entered into the regression equation, explained $7 \%$ of the change in marriage satisfaction scores in addition to the socio-demographic variables $\left(F(2,507)=20.70, \Delta R^{2}=.07, p<\right.$ $.001)$. The last model created explained approximately $12 \%$ of the change in marriage satisfaction scores as a whole, and the last model (Stage 2) had a low effect size $\left(F(7,507)=10.27, \Delta R^{2}=.12, p<.001\right)$.

In the first stage, only the income level $(\beta=.13, t(509)=2.45, p<.05)$ among the variables entered in the regression equation was a significant predictor of the change in marriage satisfaction. However, other sociodemographic variables were not a significant predictor of marital satisfaction scores. In the second stage, the interpersonal competence entered in the regression equation and self-efficacy to manage work-family conflict was a positive significant predictor of the change in marriage satisfaction scores when the effect of sociodemographic variables related to marital satisfaction was controlled. In other words, when the effect of sociodemographic variables related to marital satisfaction was controlled in this sample, the marital satisfaction of working women with high interpersonal competence and high self-efficacy to manage work-family conflict was also high. 


\section{Discussion and Conclusion}

As a result of the study, it was found that level of education (Kendir \& Demirli, 2016; K1lbitmez, 2018) and monthly income (Güngör, 2019; Kendir \& Demirli, 2016; Taşköprü, 2013) increase as the level of marriage satisfaction increases in the working women. It was found that the marriage style is a phenomenon affecting the satisfaction of the marriage, and the marriage satisfaction is lower for those who marry with love / flirting by marriages. (Güngör; 2019; Houser, 2009; Kendir \& Demirli, 2016). It was also revealed that women with more children had lower marriage satisfaction (Kılbitmez, 2018; Taşköprü, 2013). Another factor that reduces marital satisfaction is the duration of marriage. It has been determined that satisfaction with marriage decreases as the duration of marriage increases (Kilbitmez, 2018). It is concluded that the age difference between spouses is not related to marital satisfaction (Çağ, 2011; Kavak, 2018; Kendir \& Demirli, 2016). In addition, the age of marriage was not found to affect the satisfaction of individuals from their marriage (Acar, 1998; Bahr, Chappell, \& Leigh, 1983). It is not known how having more than one marriage affects women's marital satisfaction. Other results of the study are that when the interpersonal competencies of women are high, and their self-efficacy to manage workfamily conflict is high, their satisfaction level from their marriage is also high. Considering the research results and limitations, the following recommendations can be made: 1 . Since people with weak interpersonal competence and self-efficacy skills in managing work-family conflict are likely to experience problems in their interpersonal relationships, trainings that will improve their skills to manage work-family conflict can be provided to women experiencing work-family conflict. 2 . In order to deal with the problems and problems experienced in the marriage in a positive way, interpersonal relations development programs and pre-marriage training programs can be delivered to married and engaged couples. 


\section{Giriş}

Evliliğin psikolojik ve kültürel bir olay olduğu, kadının ve erkeğin birbirlerine fizyolojik ve aynı zamanda psikolojik olarak ihtiyaç duyduğu düşünülmektedir (Tarhan, 2005). Ayrıca, evliliğe geçmişte verilen anlamla şimdi verilen anlamın aynı olmadığı ve her külttürde evliliğin farklı biçimde yaşandığı belirtilmektedir (Tarhan, 2005). Kadınlar da erkekler de kendilerine özgü birtakım düşünceler ya da bir dizi sosyal, kültürel ve bireysel nedenler sonucu evlenmeye karar verirler. Bu bağlamda bireylerin evliliğe ilişkin düşünceleri ve evlenme nedenlerine bağ lı olarak evliliğin her evli çift için farklı amaç ve işlevlerinin olduğu söylenebilir. Bireylerin evlilik kararı almasını sağlayan gerekçeler değerlendirildiğinde, genel olarak evlilik yaşamının, iki kişinin biyolojik, sosyal ve psikolojik ihtiyaçlarını karşılamaya dönük olarak gerçekleştirildiği bilinmektedir (Kahraman, 2011). Biyolojik açıdan ele alındığında cinsel ihtiyaçları karşılamak evliliğin en önemli işlevlerinden birisidir. Psikolojik ve sosyal ihtiyaçlar açısından ele alındığında ise birlikte güven içinde olma, korunma, dayanışma içinde olunduğunun hissedilmesi, geleceğe güvenle bakabilme, toplumda bir yer edinebilme, eşlerin birbirlerinden onur ve gurur duyabilmelerinin de evlilik yoluyla karşılanabildiği görülmektedir. İnsan için en temel ihtiyaçlardan biri olan sevgi de, genellikle evlilik ilişkisi içinde karşılanmakta, acı ve tatlı yaşantılar paylaşılabilmekte ve birliktelik duygusu yaşanmaktadır. Böylece evlilikte eşler arasında psikolojik ihtiyaçlar da giderilmektedir (Özgüven, 2009). Bireylerin hangi nedenlerle evlendikleri incelendiğinde mutlu ve iyi bir yaşam, statü, otorite ve bağımsızlık kazanma, evli insanların toplumun çoğunluğunu oluşturması, ekonomik etkenler, sahiplenme duygusu, doğru insanı bulduğuna inanma, yaşamı bir eşle paylaşma, geleneklere uyma, toplumda sosyal bir statü kazanma, aile özlemini giderme, kendini güvende hissetme, yalnız kalmaktan korkma, çocuk sahibi olabilme, evlilikle toplum tarafından kabul edilen cinsel birlikteliğe izin verilmesi, aile baskısından kurtulma gibi nedenlerin olduğu görülmektedir (Şen, 2009). Özgüven, Ekici, Argun ve Dilek'e (2014) göre evlilik ve aile kurumunun; toplumda bir statüye kavuşma, ekonomik ihtiyaçları karşılama, üreme, çocukların eğitimini planlama, çocuklara din eğitimi verme, birlikte boş zaman etkinliklerini gerçekleştirme, aile üyelerinin birbirlerini koruması, karşılıklı olarak sevgi ihtiyacını giderme ve son olarak cinsel doyum elde etme olmak üzere yedi temel işlevi bulunmaktadır.

Evli bireylerde yukarıda sözü edilen işlevlerin yerine getirilmesi bireylerin evlilik doyumlarını artırmalarına yardımcı olurken, bu işlevlerin yerine getirilmemesi evlilik doyumunu azaltabilmekte ve eşler için istenmeyen bir dizi sonuca neden olabilmektedir. Bu bağlamda, evlilik doyumu eşin ilişkiye ya da evliliğe ilişkin genel değerlendirmesidir ki, bu değerlendirme kişinin yaşadığı ilişkiden tatmin olup olmadığını belirler. Bu yüzden de doyum bir romantik iliş̧kinin belki de en önemli ögesidir. Bir ilişkiden doyum sağlayan taraf ya da taraflar daha derin bir ilişki yaşarlar. Doyum, ilişkide olmaktan duyulan mutluluğu, ilişkiye bağlllı̆̆ı, eşe güven duymayı, çatışma oranının azalmasını, eşe yıkıcı davranışlarda bulunmamayı, onu korumayı, onun mutluluğu için çaba göstermeyi gerektirir (Solmuş, 2011). Sokolski ve Hendrick (1999) evlilik doyumunu evlilik yaşantısında verilen kararlarda söz sahibi olma, kazancı, çalışmayı ve sorunları paylaşma gibi çevresel ve eşlerin birbirlerine duyduğu sevgi, karşlıklı yaşanan cinsel doyum, eşler arasındaki sağlıklı iletişim gibi kişisel yönlerden eşlerin elde ettiği psikolojik memnuniyet olarak tanımlamışlardır (Akt., Buluş ve Bağcı, 2016). Genel olarak evlilikte doyum düzeyi yüksek olan çiftler, eşlerini takdir eder ve eşlerini ödüllendirirler, eşleriyle ortak yaşam alanları yaratmaya çalışırlar, gündelik olayları, anılarını paylaşırlar, ortak anılar yaratmaya çalışırlar, eşlerine sözel ya da sözel olmayan yollarla varlıklarını, onların kendileri için değerli olduklarını hissettirirler ve iki tarafın da hoşlandığı ortak etkinliklerde bulunurlar (Solmuş, 2011).

Bir evliliğin kalitesini ve eşlerin evlilik doyumunu çok sayıda faktörün etkileyebileceğini söylemek mümkündür. $\mathrm{Bu}$ faktörlerin başında sosyo-demografik özellikler gelmektedir. Yapılan araştırmalar çalışan kadınlarda öğrenim düzeyi (Kendir ve Demirli, 2016; Kılbitmez, 2018) ve aylık gelir (Güngör, 2019; Kendir ve Demirli, 2016; Taşköprü, 2013) arttıkça evlilik doyumunun artma eğiliminde olduğunu göstermektedir. Evlilik biçiminin evlilik doyumunu etkileyen bir durum olduğu, evlilik doyumunun görücü usulü ile evlenenlerde severek/flört ederek evlenenlerle karşılaştırıldığında daha düşük olduğu bulunmuştur (Güngör; 2019; Houser, 2009; Kendir ve Demirli, 2016). Yine sahip olduğu çocuk sayısı fazla olan kadınların evlilik doyumunun daha düşük olduğu ortaya çıkmıştır (Kılbitmez, 2018; Taşköprü, 2013). Evlilik doyumunu azaltan bir diğer faktör ise evlilik süresidir; evlilik süresi arttıkça evlilikten alınan doyumun azaldığı belirlenmiştir (Kılbitmez, 2018). Eşler arasındaki yaş farkının evlilik doyumu ile ilişkili olmadığı sonucuna ulaşılmıştır (Çăğ, 2011; Kavak, 2018; Kendir ve Demirli, 2016). Ayrıca evlilik yaşının bireylerin evliliklerinden aldıkları doyumu etkilemediği sonucuna ulaşılmıştır (Acar, 1998; Bahr, Chappell ve Leigh, 1983). Birden fazla evlilik yapmış olmanın kadınların evlilik doyumunu nasıl etkilediği ise bilinmemektedir.

Sosyo-demografik özelliklerin dışında genel olarak araştırmacılar, kişilik özellikleri; kendilik saygısı, eşlerin birbirine güveni; psikolojik ya da fiziksel sağlık sorunları; bağlanma, cinsellik; ilişkinin süresi ve statüsü; sınırlar ve sınırların korunması; değerler ve tutumlarda uzlaşma; eşe yönelik algılar ve yüklemeler; ebeveynler arası ilişkiler; kendini açma, iletişim ve empati; idealizasyon; çatışma yönetimi; kabul edilmek/reddedilmek; sosyal destek; beklentilerin uyumu ve ortak değerleri gibi faktörlerin evlilik doyumunu etkileyebileceğini bulmuşlardır (Bradbury, Fincham ve Beach, 2000; Solmuş, 2011). 
Lewis ve Spanier (1979) ile Spanier ve Lewis (1980) çalışmalarında, çiftlerin evlilik kalitelerini etkileyen üç grup değişkenden oluşan bir model önermiştir. Bu üç grup değişken: kişisel ve sosyal kaynaklar (benlik saygısı, ruhsal ve fiziksel iyi oluş gibi her bireyin evliliğe getirdiği kaynaklar olarak kavramlaştırılmaktadır), yaşam doyumu (sosyal-ekonomik yeterlilik, eşin çalışmasından duyulan memnuniyet) ve eş etkileşiminden elde edilen ödüllerdir (eşe duyulan sayg1, rol uyumu, iletişimin etkililiği). Kişisel ve sosyal kaynaklar, evlilik öncesi faktörlerden etkilenmektedir ve bu faktörler arasında eş adaylarının birbirine benzerliği, her bir bireyin kişisel kaynakları, ebeveyn modelleri, ebeveyn ve arkadaştan evlilik için alınan desteği ifade etmektedir. Bu araştırmacılar, evlilik öncesi 1rk, sosyo-ekonomik statü, dinî inançlar, zekâ ve yaş benzerliği ne kadar yüksekse evlilik niteliğinin de o kadar yüksek olabileceğini belirtmektedir. Ayrıca bu araştırmacılara göre bireyin kişisel özelliklerinden duygusal kararlılık, eğitim düzeyi, sosyal sınıf, evlilik yaşı, evlilik öncesi eşle tanışıklık düzeyi, kişiler arası işlevsellik, olumlu benlik kavramı ve fiziksel sağlık evliliklerin evlilik kalitesi üzerinde önemli etkilere sahip olabilir. Modelde ikinci grupta yaşam doyumu yer almaktadır. Yaşam doyumu, ekonomik açıdan iyi olmayı, kadınların iş statüsünü, ev halkının sayısını içermektedir. Modelin üçüncü grubunu eşle etkileşimden elde edilen ödüller oluşturmaktadır. Bu ilişki faktörleri, dışsal faktörlerden ziyade çiftler arasındaki gerçek ilişkilere odaklanır. Bu faktörler içerisinde olumlu kabul, evlilikten elde edilen duygusal faydalar, iletişim, etkileşim ve rol uygunluğu bulunmaktadır. Çoğunlukla eşe karşı olumlu duyguları ifade eden olumlu kabul; fiziksel ve cinsel çekiciliği, cinsel doyumu, duygu ve saygının ifadesini, duygusal bağımsızlığı, kişisel gelişimi cesaretlendirmeyi, otonomi duygusu ve eşitliği içerir. Etkileşim; zamanı birlikte geçirme, aktivitelerin ve ilginin paylaşılmasını, rol uygunluğu ise karşılıklı rol beklentileri konusundaki anlaşmayı, rol paylaşımını ve birbirini tamamlayabilmeyi içerir. Bu bağlamda, evlilik doyumuyla ilişkili olabilecek bir değişkenin kişiler arası yeterlilik olabileceği düşünülmektedir. Çünkü, kişiler arası yeterlilik kişilerin sosyal becerilerinin toplamı olarak nitelendirilebilecek, ilişki başlatma ya da makul olmayan istekleri reddetme, duygusal destek ve çatışma yönetimi şeklinde bir dizi kişiler arası beceriyi içermektedir. Araştırmacılar, bilgi, beceri ve motivasyon yapıları gibi temel bilişsel bileşenlerden oluşan kişiler arası yetkinlikten yoksun olan bireylerin yakın ilişki kurmada ve bu ilişkini sürdürmekte yetersiz olabilecekleri ifade etmektedir (Baytemir, 2014, 2016; Buhrmester, Furman, Wittenberg ve Reis, 1988; Spitzberg ve Cupach, 2012). Ancak kişiler arası yeterlilik ile evlilik uyumu arasında ilişki üzerine ulusal literatürde yürütülmüşs sınırlı sayıda araştırma mevcuttur (Şahin ve Gizir, 2013). Yurt dışında yapılmış çalışmalarda ise kişiler arası becerilerdeki eksikliklerin evlilik ilişkilerinde olumsuz duygusal sonuçlara aracılık ettiği görülmektedir (Spitzberg ve Cupach, 2012).

Ailede her iki eşin de çalışması, eve ek bir maddi getiri sağlayarak birçok ihtiyacın karşılanmasına yardımcı olmasına rağmen, uzun yıllar boyunca kadının yeri ev ile sınırlandırılmış, ev işleri ve çocuk bakımı kadının en önemli işlevi olarak görülmüştür (Arslan, 2012). Türkiye'de kadın istihdamının tarihine bakıldığında 1950'li yıllardan itibaren sanayileşme ve köyden kente göçün hızlandığı dönemlerden itibaren kadının iş gücü piyasasının içinde aktif rol almaya başladığı görülmektedir (Kızılgöl, 2012). Yapılan bir araştırma, çalışan kadınların daha fazla bağımsız davranabildiğini ve toplumda daha fazla takdir edildiğini ve bunun sonucu olarak genel sağlık, yaşam doyumu ve benlik saygılarının genel olarak daha yüksek olduğunu, ümitsizlik, güvensizlik ve kaygının ise yine çalışan kadınlarda çalışmayan kadınlara göre daha düşük olduğunu göstermiştir (Çilli ve diğ., 2004). Her ne kadar kadınların çalışma hayatında olması psikolojik sağlıklarını olumlu yönde etkilese de çalışan kadınların iş ve aile hayatlarında üstlendiği roller, talep, ihtiyaç ve beklentilerin aynı anda ortaya çıkması iş ve aile hayatlarında çatışmalar yaşamalarına neden olabilmektedir (Çarıkçı ve Çelikkol, 2009). Arslan'a göre (2012) kadının iş hayatına girmesi evde geleneksel rolleri, işte de modern iş koşullarına uygun rolleri yerine getirmesi beklentisini ortaya çıkarması aile ve iş hayatında erkeklere oranla daha fazla çatışma durumu yaşamalarına neden olabilmektedir. Her ne kadar kreşler, temizlik şirketleri, yemek servisleri gibi çalışan kadınların aile içi rollerini hafifletecek iş sahaları bulunsa da çalışan kadınların aile içi rollerinin tamamını devretmesi mümkün olmamaktadır (Çelik ve Turunç, 2009). Sonuç olarak, bu durum çalışan kadınların gerçekleştirdikleri roller gereği iş ve aile çatışmaları yaşamalarına ve evlilik doyumlarının azalmasına neden olabilmektedir. Ancak ulusal literatür incelendiğinde iş-aile çatışmasıyla ilişkili çalışmaların psikolojik niteliklerden çok demografik özellikler ile yürütüldüğü görülmektedir (Amanvermez ve Denizli, 2016). Oysaki kişilerin kendileri ile ilgili değerlendirmeleri ve psikolojik özellikleri de iş-aile çatışmasını ele almada ve olumsuz etkilerini azaltma konusunda önemli bir değişkendir (Amanvermez ve Denizli, 2016). Bu bağlamda, bir psikolojik değişken olarak çalışan kadınların işaile çatışmasını yönetmedeki öz-yetkinlikleri de evlilik doyumlarını etkileyebilecek bir değişken olabilir. Özyetkinlik kavramı, insanların farklı yaşam rollerinden kaynaklanan çatışmayı nasıl algıladıklarını ve yönettiklerini anlamak için psikoloji literatürde sıklıkla ele alınan bir değişkendir (Hennessy ve Lent, 2008). Öz yetkinlik, kişinin belirli davranışları veya eylem planlarını gerçekleştirme kabiliyetleri hakkındaki kişisel inançlarını içermektedir (Bandura, 2012). Öz-yetkinlik inancı, insanların davranış tercihlerini ve davranış ortamlarını, engellerle karşı karşıya kaldıklarında ısrar etmeyi, bilişsel strateji kullanımlarını ve duygusal durumlarını belirlemeye yardımcı olmayı kapsamaktadır (Hennessy ve Lent, 2008). Her iki rolün birbiriyle çelişmediği durumlarda iş veya aile rollerini gerçekleştirme konusunda oldukça yetenekli olmak mümkün olabilir. Ancak, her iki rolün gereksinimlerini karşılamaya çalışırken ortaya çıkan karşılıklı çatışmayı müzakere etme yeteneği, iş-aile çatışması deneyimi, yönetimi ve sonuçları ile daha yakından bağlantılı olabilecek kendine özgü bir başa çıkma biçimini 
gerektirir (Hennessy ve Lent, 2008). Dolayısıyla, burada kişinin iş ve aile çatışmasını etkilediği düşünülen önemli bir değişken, kişinin bir işi yapabilecek yeteneğinin varlığına dair olan inançları, başka bir ifadeyle sahip olduğu öz-yetkinlik düzeyleridir. Yani bir kişinin işinin ve ailesinin gerektirdiği rol çatışmasını düzenleyebileceğine dair sahip olduğu iş-aile çatışmasını yönetme öz yetkinliğidir (Amanvermez ve Denizli, 2016). Bu doğrultuda, bu araştırmanın amacı ilk olarak çalışan kadınlarda evlilik doyumuyla ilişkili sosyo-demografik değişkenleri incelemek ve ilişkili sosyo-demografik değişkenlerin etkisini kontrol ederek çalışan kadınlarda evlilik doyumunun yordayıcısı olarak kişiler arası yeterlilik ve iş-aile çatışmasını yönetme öz yetkinliğini incelemektir.

\section{Yöntem}

\section{Araştırmanın Deseni}

Bu araştırma çalışan kadınlarda evlilik doyumunun yordayıcısı olarak kişiler arası yeterlilik ve iş-aile çatışmasını yönetme öz yetkinliğinin incelendiği ilişkisel tarama modelinde bir araştırmadır (Howitt ve Cramer, 2014). Bu araştırma modeli, belirli bir zaman dilimi içerisinde değişkenler arasındaki geçici ilişkileri herhangi bir müdahalede bulunmadan incelemeyi amaçlamaktadır (Howitt ve Cramer, 2014). Bu araştırmada da benzer şekilde, çalışan kadınlarda evlilik doyumunun kişiler arası yeterlilik ve iş-aile çatışmasını yönetme öz yeterliliğiyle ilişkisi araştırmanın gerçekleştirildiği zaman dilimi içerisinde, araştırmanın çalışma grubunu oluşturan bireylerde herhangi bir müdahalede bulunulmadan incelenmiştir.

\section{Çalışma Grubu}

Araştırmanın çalışma grubunu Ankara, Malatya, Samsun ve Kastamonu illerinde farklı kurum ve kuruluşlarda görev yapmakta olan ve uygun örnekleme yoluyla ulaşılan 515 çalışan kadın oluşturmuştur. Araştırmanın çalışma grubunu oluşturan kadınların yaş aralığ 20 ile 62 arasında olup, yaş ortalamaları 38.31'dir $(S S=8.23)$. Çalışma grubunu oluşturan kadınlar, ebe, esnaf, hemşire, memur, mühendis, öğretmen, sekreter, satış danışmanı, serbest işçi, psikolojik danışman, sağlık uzmanı, muhasebeci, kamu görevlisi, kuaför, kasiyer, tasarımcı, temizlik personeli gibi farklı meslek gruplarına mensuptur. Çalışma grubunu oluşturan kadınlar çoğunlukla üniversite mezunu ( $n=226, \%$ 43.9) olup, 1 ila 5 yıl arasında evlilik süresine sahiptir ( $n=127, \% 24.7)$. Çalışma grubunu oluşturan kadınların ilk evlilik yaşı 13 ila 48 arasında değişmekte olup, ortalama ilk evlilik yaşları 24.79'dur (Ort. $=24.79, S S=4.86$ ). Katılımcıların eşleri ile aralarındaki yaş farkı 0 ila 21 arasında değişmekte olup, eşleriyle aralarındaki ortalama yaş farkı $3.44(S S=2.99)$ yıldır. Çalışan katılımcıların büyük bir kısmının ilk evliliği olup ( $n=495, \%$ 96.1), severek/anlaşarak $(n=344, \%$ 66.8) evlenmiştir. Katılımcıların aylık gelir düzeyleri çoğunlukla .3201 ile 4000 TL $(n=122, \%$ 23.7) arasındadır. Son olarak katılımcıların sahip oldukları çocuk sayısı 0 ila 6 arasında değişmekte olup, katılımcılar çoğunlukla 2 çocuk sahibidir $(n=196, \% 38.1)$.

\section{Veri Toplama Araçları}

Araştırma kapsamında kullanılan Demografik Bilgi Formu (DBF), Kişiler arası Yeterlilik Ölçeği (KYÖ), İş-Aile Çatışmasını Yönetme Öz-yeterliği Ölçeği (İAÇYÖÖ) ve Evlilik Doyum Ölçeği (EDÖ) hakkındaki bilgiler aşağıda sunulmuştur:

Demografik Bilgi Formu. Araştırmaya katılan çalışan kadınların yaşları, öğrenim düzeyleri, evlilik yılları, ilk evlilik yaşları, eşleri ile aralarındaki yaş farkı, kaç yıllık evli oldukları, evlilik biçimleri ve aylık gelirleri hakkında bilgi toplamak amacıyla araştırmacılar tarafından geliştirilmiştir.

Kişilerarası Yeterlilik Ölçeği. Kişiler arası Yeterlilik Ölçeği (Interpersonal Competence Questionnaire) Burhmester ve diğerleri (1988) tarafindan bireylerin kişiler arası becerilerini değerlendirmek amacıyla geliştirilmiştir. Beşli likert tipinde olan bu ölçek beş alt boyuttan oluşmaktadır. Bu alt boyutlar çatışma çözme, ilişki başlatma, duygusal destek, etki bırakma ve kendini açmadır. Her bir alt boyut sekiz maddeden, ölçek ise toplam 40 maddeden oluşmaktadır. Katılımcılar her bir ölçek ifadesinin kendileri için ne düzeyde uygun olduğunu 'Hiçbir zaman iyi değilim'den (1) 'Her zaman iyiyim'e (5) uzanan seçeneklerden birini işaretleyerek ifade etmektedir. Ölçek alt boyutlar bağlamında ya da toplam puan alınarak kullanılabilmektedir (Baytemir, 2014; 2016). Bu çalışmada katılımcıların genel kişiler arası yeterlilik düzeylerinin belirlenmesi amaçlandığından ölçek toplam puanı kullanılmıştır. Ölçekten alınabilecek puan 40 ila 200 arasında değişmekte olup, yüksek puan bireylerin kişiler arası ilişkilerdeki yeterlilik algılarının yüksek olduğunu göstermektedir. Kişiler arası yeterlilik ölçeğinin ilk olarak ergenler üzerinde geçerlik ve güvenirliğini inceleyen Baytemir (2014) daha sonra ölçeğin üniversite öğrencileri üzerinde de geçerlik ve güvenirliğini araştırmıştır (Baytemir, 2016). Bu araştırma sonucunda, ölçeğin ergenler üzerinde ulaşılan beş faktörlü yapısının üniversite öğrencilerinde de iyi uyum gösterdiği bulunmuştur. Ölçeğin, Baytemir (2016) tarafından tamamı için bildirilen Cronbach alpha iç tutarlılık değeri .94 iken, ölçeğin tamamının bu araştırma için hesaplanan Cronbach alpha $(\alpha)$ iç tutarlılık katsayısı .95'tir.

İş-Aile Çatışmasını Yönetme Öz-yeterliği Ölçeği. Bireylerin aile ve iş rollerine ilişkin çatışmaları yönetebilme yeteneğine olan inancını değerlendirebilmek amaciyla Cinnamon (2003, akt., Hennesy, 2005) tarafindan 
geliştirilen İAÇÖÖ kullanılmıştır. Orijinal ölçek İbranice dilinde, 10 madde olarak geliştirildikten sonra Hennessy (2005) tarafından İngilizce diline uyarlama, geçerlilik ve güvenilirlik çalışmaları gerçekleştirilmiştir. Bu çalışma sonucunda, ölçeğin orijinal faktör yapısına benzer şekilde aile-iş çatışmasını yönetme ve iş-aile çatışmasını yönetme öz yeterliliği boyutlarından oluştuğu ancak iki maddenin (orijinal ölçekte ikinci ve beşinci) çalışmadığ bildirilerek sekiz maddelik form oluşturulmuştur. Hennessy (2005) tarafından ölçeğin tamamı için bildirilen iç tutarlılık katsayısı .93, test tekrar test güvenilirliği ise .62 olarak bildirilmiştir. İAÇÖÖ İngilizce formunun Türkçe diline uyarlama, geçerlilik ve güvenilirlik çalışmaları Amanvermez ve Denizli (2016) tarafından gerçekleştirilmiştir. Bu çalışma sonucunda, ölçeğin iki faktörlü yapısının Türk örnekleminde iyi bir uyum gösterdiği ve ölçeğin tamamının güvenilirliğinin .95 olduğu bildirilmiştir. Ölçek alt boyutlar bağlamında ya da toplam puan alınarak kullanılabilmektedir (Amanvermez ve Denizli, 2016). Bu çalışmada çalışan kadınların genel iş ve aile çatışması düzeyinin ölçülmesi amaçlandığından toplam puan kullanılmıştır. Ölçeğin bu çalışma için hesaplanan Cronbach alpha iç tutarlılık katsayısı .95 'tir.

Evlilik Doyum Ölçeği. Katılımcıların evlilik doyum düzeylerini ölçmek amacıyla tek maddelik bir sorudan yararlanılmıştır. Tek maddelik ölçekler benlik saygısı (Robins, Hendin ve Trzesniewski, 2001), mutluluk (AbdelKhalek, 2006), iş doyumu (Wanous, Reichers ve Hudy, 1997), stres belirtileri (Elo, Leppänen ve Jahkola, 2003), dindarlık (Abdel-Khalek, 2007), genel sağlık (DeSalvo ve diğ., 2006) gibi farklı psikolojik özelliklerin ölçülmesinde psikoloji literatürde sıklıkla kullanılmaktadır. Katılımcılar "Eşinizle evlilik doyumunuzu 1 ila 10 arası bir puan ile değerlendirmeniz istense kaç verirdiniz işaretleyiniz?” sorusunu 1 (Çok Kötü) 'den 10 (Çok İyi)'a uzanan seçeneklerden birini işaretleyerek cevaplamaktadır. Bireylerin alabilecekleri puanlar 1 ila 10 arasında değişmekte olup, aldıkları puanların yüksekliği evlilik doyumunun yüksek olduğuna işaret etmektedir.

\section{Veri Toplama Süreci}

Araştırmaya konu olan veriler Ankara, Malatya, Samsun ve Kastamonu illerinde farklı kurum ve kuruluşlarda görev yapmakta olan çalışan kadınlardan 2019 yılının Ocak-Mart ayları arasında birinci araştırmacı tarafından yüz yüze uygulamalar yapılarak toplanmıştır. Katılımcılar veri toplama araçlarını yaklaşık olarak 20 dakikada cevaplamıştır.

\section{Veri Analizi}

Tüm istatistiksel işlemler ve analizler SPSS 23 programı aracılığıyla gerçekleştirilmiştir. Araştırmada kullanılacak hipotez testleri gerçekleştirilmeden önce her bir değişkenin frekans dağılımları, veri setinde her bir değişkenin sahip olduğu kayıp değerler, veri setindeki aykırı değerler ve kullanılan hipotez testlerinin varsayımları incelenmiştir. Frekans dağılımlarının incelenmesi sonucunda, öğrenim düzeyi, aylık gelir düzeyi, evlilik biçimi değişkenleri yeniden gruplandırılmıştır. Veri setindeki kayıp değer miktarının \% 0 ila \% 2.7 arasında değiştiği görülmüştür. Bu sınırlı sayıda kayıp değere beklenti-maksimizasyon algoritması kullanılarak veri atama işlemi gerçekleştirilmiştir (Schlomer, Bauman ve Card, 2010). Ancak veri setindeki kayıp değer miktarı değişken bazında \% 5 ve altında olduğunda bu miktar önemsiz bir miktardır ve farklı veri atama türleri benzer sonuçlar verme eğilimindedir (Hair ve diğ., 2014; Tabachnick ve Fidell, 2012). Katılımcıların yaşı, öğrenim düzeyi, evlilik yılı, evlilik yaşı, eşi ile arasında olan yaş farkı, kaç yıllık evli olduğu, evlilik biçimi ve aylık geliri hakkında bilgi vermek amacıyla betimsel istatistiklerden yararlanılmıştır. Evlilik doyumunun öğrenim düzeyi, evlilik yılı, evlilik yaşı, eşi ile arasında olan yaş farkı, kaç yıllık evli olduğu, evlilik biçimi ve aylık geliri, iş-aile çatışmasını yönetme öz yetkinliği, kişiler arası yeterlilik ile ilişkisi Pearson korelasyon analizi aracılığıyla incelenmiştir. Literatürde sıralama türünde cevaplama kategorisine sahip Likert tipi ölçeklerin ne zaman eşit aralıklı ölçek ya da ne zaman sıralama tipi bir ölçek olarak kullanılabileceğine ilişkin görüş farklılıkları olmasına rağmen (Jamieson, 2004; Knapp, 1990; Norman, 2010), son yıllarda gerçekleştirilen araştırmalar tutarlı bir şekilde sıralama tipindeki ölçeklerden elde edilen verilerin belirli koşulları yerine getirdiğinde eşit aralıklı bir ölçek gibi kullanılabileceğini göstermektedir. Bu koşullar sırasıyla sıralama tipi ölçekte cevaplama kategorisi sayısının beş ya da daha fazla olması, cevaplama kategorilerinin azalış ya da artış şeklinde mantıksal bir sıra izlemesidir (Byrne, 2012; Finney ve DiStefano, 2013; Rhemtulla, Brosseau-liard ve Savalei, 2012). Bu nedenle, bu araştırmada öğrenim düzeyi, evlilik yılı ve aylık gelir değişkenleri bu koşulları yerine getirdiğinden eşit-aralık türünde ölçekler olarak kabul edilmiştir. Evlilik doyumuyla ilişkili sosyo-demografik değişkenlerin etkisi kontrol edildiğinde, iş-aile çatışmasını yönetme öz yetkinliği, kişiler arası yeterliliğin evlilik doyumuyla ilişkisi hiyerarşik regresyon analizi aracılığıyla incelenmiştir. Analizler gerçekleştirilmeden önce uygun olan analizlerde normallik, doğrusallık, regresyon hatalarının normalliği, eş varyanslılık ve çoklu doğrusallık varsayımları incelenmiş ve karşılandığı görülmüştür (Hair ve diğ., 2014; Tabachnick ve Fidell, 2012). Tüm analizlerde Tip I hata düzeyi .05 olarak kabul edilmiştir.

\section{Etik Konular}

Veri toplama araçları uygulanmadan önce etik kurul onayı alınmıştır. Veri toplama aracı katılımcılara uygulanmadan önce araştırmanın etik ilkeleri, gönüllülük ve gizlilik ve araştırmadan çekilme hakkı ile ilgili bilgi verilmiştir. Tüm katılımcılar araştırmaya gönüllü olarak katılmıştır. 


\section{Bulgular}

Tablo 1'de değişkenler arasındaki ilişkinin gücünü ve yönünü belirleyebilmek amac1yla gerçekleştirilen Pearson korelasyon analizi sonuçları ve değişkenlerin aritmetik ortalama ve standart sapma değerlerini içeren betimsel istatistikler görülmektedir.

Tablo 1

Değişkenler Arasındaki Pearson Korelasyon Katsayıları

\begin{tabular}{|c|c|c|c|c|c|c|c|c|c|c|c|}
\hline & 1 & 2 & 3 & 4 & 5 & 6 & 7 & 8 & 9 & 10 & 11 \\
\hline \multicolumn{12}{|l|}{ 1. EDÖ } \\
\hline 2. Öğrenim düzeyi & $.17 * *$ & & & & & & & & & & \\
\hline 3. Evlilik süresi & $-.10 *$ & $-.26 * *$ & & & & & & & & & \\
\hline 4. Evlilik yaş1 & .05 & $.40 * *$ & $-.43 * *$ & & & & & & & & \\
\hline 5. Yaş fark1 & -.09 & $-.16 * *$ & $.23 * *$ & $-.25 * *$ & & & & & & & \\
\hline 6. Evlilik sayıs1 & -.02 & -.05 & $-.09^{*}$ & .07 & .06 & & & & & & \\
\hline 7. Evlilik biçimi & $-.12 * *$ & $-.31 * *$ & $.25^{* *}$ & $-.17 * *$ & $.19 * *$ & .05 & & & & & \\
\hline 8. Çocuk sayısı & $-.14 * *$ & $-.24 * *$ & $.58 * *$ & $-.38 * *$ & $.20 * *$ & -.01 & $.26 * *$ & & & & \\
\hline 9. Aylık gelir & $.19 * *$ & $.59 * *$ & $-.10 *$ & $.22 * *$ & $-.09 *$ & -.03 & $-.26 * *$ & $-.15 * *$ & & & \\
\hline 10. KYÖ & $.24 * *$ & .04 & -.02 & -.01 & .05 & .03 & $-.12 * *$ & -.05 & .03 & & \\
\hline 11. İAÇYÖÖ & $.25 * *$ & .05 & .14 & .01 & .02 & -.08 & $-.14 * *$ & .04 & .05 & $.51 * *$ & \\
\hline Ortalama & 7.63 & 4.23 & 2.98 & 24.79 & 3.44 & 1.04 & 1.33 & 1.44 & 3.64 & 128.98 & 49.27 \\
\hline Standart Sapma & 2.03 & 1.34 & 1.66 & 4.86 & 2.99 & .19 & .47 & .99 & 1.51 & 26.85 & 13.77 \\
\hline
\end{tabular}

Not. Öğrenim düzeyi: 1: İlkokul ve altı, 6: Lisansüstü, Evlilik süresi: 1: 0-5 yıl, 6: 26 yıl ve üzeri, Evlilik sayısı: 1: Bir kez, 2: İki ya da daha fazla, Evlilik biçimi: 1: Severek /Anlaşarak, 2: Görücü usulü, Aylık gelir: 1: $1600 \mathrm{TL}$ ve altı, 6: $4801 \mathrm{TL}$ ve üzeri., $N=515, p<.05^{*}$, en az $p$ $<.01^{* *}$ düzeyinde anlamlıdır. Normal koşullarda, nominal değişkenlere ilişkin ortalama ve standart sapma rapor edilmez ancak SPSS bu değişkenleri analizlerde bir değer olarak değerlendirmektedir ve bu değerler olmadan regresyon analizi sonuçlarının doğruluğu kanıtlanamaz.

Tablo 1'de görüldüğü üzere evlilik doyumu puanları öğrenim düzeyi $(r=.17, p<.01)$, aylık gelir $(r=.19, p<$ $.01)$, kişiler arası yeterlilik puanları $(r=.24, p<.01)$ ve iş-aile çatışmasını yönetme öz yetkinliği $(r=.25, p<.01)$ puanlarıyla düşük düzeyde pozitif yönde ilişkiliyken, evlilik süresi $(r=-.10, p<.05)$, evlilik biçimi $(r=-.12, p<$ $.01)$, çocuk sayısı $(r=-.14, p<.01)$ değişkenleriyle düşük düzeyde negatif yönde ilişkilidir. Başka bir ifadeyle, bu örneklemde öğrenim düzeyi, aylık gelir düzeyi, kişiler arası yeterliliği ve iş aile çatışmasını yönetme öz yetkinliği yüksek çalışan kadınların evlilik doyumu yüksek olma eğilimindeyken, görücü usulü evlenen ve çocuk sayısı fazla, evlilik süresi yüksek olan çalışan kadınların evlilik doyumu düşüktür. Ayrıca, evlilik doyumu evlilik sayısı, yaş farkı ve evlilik yaşıyla ilişkili değildir.

Çalışan kadınlarda evlilik doyumuyla ilişkili sosyo-demografik değişkenlerin etkisi kontrol edildiğinde kişiler arası yeterliliğin ve iş aile çatışmasını yönetme öz yetkinliğinin evlilik doyumuyla ilişkili olup olmadığını belirlemek amacıyla gerçekleştirilen hiyerarşik regresyon analizi sonuçları değişim istatistikleri Tablo 2'de, hiyerarşik regresyon analizi sonuçları ise Tablo 3'de görülmektedir.

Tablo 2

Evlilik Doyumuna İlişkin Hiyerarşik Regresyon Analizi Değişim İstatistikleri

\begin{tabular}{lccccccccc}
\hline Aşama & $R$ & $R^{2}$ & Düz $R^{2}$ & $S H$ & $\Delta R^{2}$ & $\Delta F$ & $d f_{1}$ & $d f_{2}$ & $p$ \\
\hline Aşama 1 & .23 & .05 & .04 & 1.99 & .05 & 5.67 & 5 & 509 & .001 *** \\
Aşama 2 & .35 & .12 & .11 & 1.91 & .12 & 10.27 & 7 & 507 & .001 *** \\
Aşama 2-Aşama 1 & & & & & .07 & 20.70 & 2 & 507 & .001 *** \\
\hline Not: $p<001$ *** & & & &
\end{tabular}

Not: $p<.001^{* * * *}$

Tablo 2'de görüldüğü gibi ilk aşamada regresyon denklemine girilen evlilik doyumuyla ilişkili sosyo-demografik değişkenler evlilik uyum puanlarındaki değişimin yaklaşık olarak \% 5'ini açıklamaktadır ve bu değişim anlamlıdır $\left(F(5,509)=5.67, \Delta R^{2}=.05, p<.001\right)$. İkinci aşamada regresyon denklemine girilen kişiler arası yeterlilik ve iş aile çatışmasını yönetme öz yetkinliği puanları sosyo-demografik değişkenlere ek olarak evlilik doyumu puanlarındaki değişimin \% 7'sini açıklamaktadır ve bu değişim de anlamlıdır $\left(F(2,507)=20.70, \Delta R^{2}=.07, p<\right.$ .001). Oluşturulan son model ise bir bütün olarak evlilik doyumu puanlarındaki değişimin yaklaşı olarak \% 
12'sini açıklamaktadır ve son model (Aşama 2) düşük düzeyde bir etki büyüklüğüne sahiptir $(F(7,507)=10.27$, $\left.\Delta R^{2}=.12, p<.001\right)$.

Tablo 3

Evlilik Doyumuna İlişkin Hiyerarşik Regresyon Analizi Sonuçları

\begin{tabular}{|c|c|c|c|c|c|c|}
\hline \multirow{2}{*}{ Aşama } & & \multicolumn{2}{|c|}{ Standardize Edilmemiş } & \multirow{2}{*}{$\frac{\text { Standardize }}{\beta}$} & \multirow{2}{*}{$t$} & \multirow{2}{*}{$p$} \\
\hline & & $B$ & $S E$ & & & \\
\hline \multirow[t]{6}{*}{ Aşama 1} & Sabit & 7.21 & .50 & & 14.50 & $.001 * * *$ \\
\hline & Öğrenim düz & .08 & .09 & .05 & .96 & .340 \\
\hline & Evlilik sür. & -.01 & .07 & -.01 & -.18 & .857 \\
\hline & Evlilik biçimi & -.21 & .20 & -.05 & -.1 .02 & .307 \\
\hline & Çocuk sayısı & -.18 & .11 & -.09 & -1.61 & .109 \\
\hline & Aylık gelir & .18 & .07 & .13 & 2.45 & $.015^{*}$ \\
\hline \multirow[t]{8}{*}{ Aşama 2} & Sabit & 4.52 & .66 & & 6.89 & $.001 * * *$ \\
\hline & Öğrenim düz & .06 & .08 & .04 & .79 & .431 \\
\hline & Evlilik sür. & -.06 & .06 & -.05 & -.95 & .341 \\
\hline & Evlilik biçimi & .00 & .20 & .00 & -.02 & .983 \\
\hline & Çocuk sayısı & -.16 & .11 & -.08 & -1.52 & .130 \\
\hline & Aylık gelir & .18 & .07 & .14 & 2.61 & $.009 * *$ \\
\hline & KYÖ & .01 & .00 & .13 & 2.69 & $.007 * *$ \\
\hline & İAÇÖÖ & .03 & .01 & .18 & 3.67 & $.001 * * *$ \\
\hline
\end{tabular}

Not: Öğrenim düzeyi: 1: İlkokul ve altı, 6: Lisansüstü; Evlilik süresi: 1: 0-5 yıl, 6: 26 yıl ve üzeri; Evlilik sayısı: 1: Bir kez, 2: İki ya da daha fazla; Evlilik biçimi: 1: Severek /Anlaşarak, 2: Görücü usulü; Aylık gelir: 1: 1600 TL ve altı, 6: 4801 TL ve üzeri; $p<.05^{*}, p<.01 * *, p<$ $.001 * * *$.

Tablo 3'te görüldüğü gibi ilk aşamada regresyon denklemine girilen değişkenlerden sadece gelir düzeyi $(\beta=.13$, $t(509)=2.45, p<.05)$ evlilik puanlarındaki değişimin anlamlı bir yordayıcısıdır. Ancak diğer sosyo-demografik değişkenler evlilik doyum puanlarının anlamlı bir yordayıcısı değildir. İkinci aşamada regresyon denklemine girilen kişiler arası yeterlilik ve iş-aile çatışmasını yönetme öz yetkinliği evlilik doyumuyla ilişkili sosyodemografik değişkenlerin etkisi kontrol edildiğinde evlilik doyum puanlarındaki değişimin pozitif anlamlı bir yordayıcısıdır. Başka bir ifadeyle, bu örneklemde, evlilik doyumuyla ilişkili sosyo-demografik değişkenlerin etkisi kontrol edildiğinde, kişiler arası yeterliliği yüksek ve iş-aile çatışması yönetme öz yetkinliği yüksek çalışan kadınların evlilik doyumları da yüksektir.

\section{Sonuç ve Tartışma}

Bu araştırmada ilk olarak çalışan kadınlarda evlilik doyumuyla ilişkili sosyo-demografik değişkenler incelenmiş ve daha sonra evlilik doyumuyla ilişkili sosyo-demografik değişkenlerin etkisi kontrol edildiğinde kişiler arası yeterlilik ve iş-aile çatışmasını yönetme öz yetkinliğinin evlilik doyumuyla ilişkisi incelenmiştir. Araştırmada çalışan kadınlarda öğrenim düzeyi arttıkça evlilik doyumunun artma eğiliminde olduğu bulunmuştur. Bu sonuç daha önce gerçekleştirilen ve yüksek eğitim düzeyinin yüksek evlilik doyumuyla ilişkili olabileceğini gösteren araştırma sonuçlarıyla benzerlik göstermektedir. Örneğin, Kılbitmez (2018) tarafından yapılan çalışmada eğitimi üniversite ve üstü olan bireylerin evlilik doyum düzeylerinin daha fazla olduğu sonucuna ulaşılmıştır. Aynı şekilde Kendir ve Demirli’nin (2016) yaptığı çalışmada da yüksek lisans mezunu bireylerin diğer bireylere oranla evlilik doyum düzeylerinin daha yüksek olduğu belirlenmiştir. Bu sonuçlar, eğitim düzeyi düşük olan kişilerin birbirlerine sevgilerini bildirme, iletişim kurma, herhangi bir konuda fikir beyanında bulunma, yaşanan çatışmayı olumlu bir şekilde sonlandırma, beraber vakit geçirme hususlarında çok fazla anlaşmazlıklar yaşama olasılıklarının yüksek olmasından dolayı düşük düzeyde evlilik doyumuna sahip olmalarıyla ilişkili olabilir.

$\mathrm{Bu}$ araştırmada çalışan kadınların aylık gelirleri arttıkça evlilik doyumunun da artmakta olduğu sonucuna ulaşılmıştır. Bu sonuç da daha önce gerçekleştirilen ve yüksek aylık gelirin yüksek evlilik doyumuyla ilişkili olabileceğini gösteren araştırma sonuçları ile tutarlılık göstermektedir. Örneğin, Taşköprü (2013) tarafindan yapılan bir çalışmada düşük gelir düzeyine sahip bireylerin evlilik doyumlarının orta ve yüksek gelir düzeyine sahip olanlara göre daha düşük olduğu bulunmuştur. Benzer bir şekilde Güngör (2019) tarafından yapılan bir çalışmada da aylık geliri yüksek olan kişilerin evlilik doyumlarının anlamlı bir şekilde yüksek olduğu bulunmuştur. Yıldırım (1993) ve Polat (2006) da çalışmalarında ekonomik durumun evlilik doyumunu etkilemekte olduğunu ve ekonomik seviye arttıkça evlilik doyumunun da arttığını bulmuştur (Kendir ve Demirli, 2016). Yaşam koşullarının 
güç olması dikkate alındığında, gelir düzeyi yüksek olan evli bireylerin evlilikle ilgili sorumluluklarını daha iyi yerine getirebilmeleri, bunun sonucunda da evlilik doyumlarının daha yüksek olmasıyla ilişkili olabilir.

$\mathrm{Bu}$ araştırmada evlilik biçiminin evlilik doyumunu etkileyen bir olgu olduğu, görücü usulü ile evlenenlerin severek/flört ederek evlenenlere göre evlilik doyumunun daha düşük olduğu bulunmuştur. Bu bulgular daha önce araştırılan ve severek evlenenlerin daha yüksek evlilik doyumuna sahip olabileceklerini gösteren araştırma sonuçları ile aynı doğrultuda yer almaktadır. Örneğin, Houser (2009) tarafından yapılan bir çalışma sonucunda flört ederek evlenenlerin evlilik doyumlarının daha yüksek olduğu bulunmuştur. Aynı şekilde Güngör (2019) tarafından yapılan bir araştırmada da aşk evliliği yapan evli bireylerin evlilik doyumunun mantık evliliği ve görücü usulüyle evlenenlerin evlilik doyumundan anlamlı bir şekilde yüksek olduğu sonucuna ulaşılmıştır. Kendir ve Demirli de (2016) araştırmalarında severek evlenen bireylerin diğer bireylere oranla evlilik doyum düzeylerinin daha yüksek olduğunu bulmuştur. Evlilikte sorun yaşamak kaçınılmazdır ancak birlikte bir yuva kurma arzusuyla evlenen ve aralarında sevgi ve saygı olan çiftlerin bu sorunları beraber sırtlamaları, olumsuz durum karşısında beraber hareket etmeleri ve sonuç olarak evliliklerinden de daha yüksek doyum almaları bu sonucun olası açıklamalarından biri olabilir.

$\mathrm{Bu}$ araştırmada sahip oldukları çocuk sayısı fazla olan evli kadınların evlilik doyumunun daha düşük olduğu bulunmuştur. Başka bir deyişle, çocuk sayısı arttıkça evlilikten alınan doyum azalma eğilimindedir. Bu bulgular daha önce gerçekleştirilen ve fazla çocuk sayısının düşük düzeyde evlilik doyumu ile ilişkili olabileceğini gösteren araştırma sonuçları ile paralellik göstermektedir. Örneğin, Taşköprü (2013) tarafindan gerçekleştirilen bir çalışmada çocuk sahibi olmayan kişilerin evlilik doyumlarının daha yüksek olduğu bulunmuştur. Aynı şekilde Kılbitmez (2018) tarafindan yapılan çalışmada da çocuk sayısı arttıkça evlilikten alınan doyumun azalmakta olduğu saptanmış̧ır. Çocuk iki kişi arasında yaşanan özel bir ilişkinin aile yapısına dönüşmesinde önemli bir noktadır ve çocuğun bakımı ve sorumluluğu kişisel bir yaşamdan çıkarak çocukla yaşamaya alışmak, dolayısıyla iki kişilik alana önemli bir sorumluluk almak demektir (Çağ, 2011). Bu nedenle evli çiftlerde çocukla beraber evlilik doyumunda azalma olduğu görülmektedir. Literatür incelendiğinde çocuğun evlilik üzerindeki etkisi ile ilgili farklı araştırmalar dikkat çekmektedir. Örneğin, Belsky (1990) çocukların varlığının evlilik doyumunu düşürürken, evlilik istikrarını artırdığını göstermektedir. Diğer taraftan, çocuklar evden ayrıldığında çiftlerin evlilik doyumlarının da artmakta olduğu görülmektedir (Gorchoff, John ve Helson, 2008). Bu sonucun olas1 açıklamalarından biri çocuk bakımının kadınlar için zor olması olabilir.

Araştırma bulgularından bir diğeri de evlilik süresi arttıkça evlilikten alınan doyumun azaldığıdır. Başka bir deyişle, evlilik süresi az olan, yeni evli çiftlerin evlilikten aldıkları doyum daha fazladır. Bu bulgular daha önce gerçekleştirilen ve uzun süreli evliliklerin düşük evlilik doyumu ile ilişkili olabileceğini gösteren çalışma bulguları ile benzerdir. Örneğin, Kılbitmez (2018) tarafından yapılan çalışmada evlilik süresi arttıkça evlilik doyumunun azalmakta olduğu bulunmuştur. Benzer şekilde, Taşköprü (2013) tarafından evlilik doyumu ile problem çözme becerileri, stresle başa çıkma ve evlilik süresi arasındaki ilişkinin araştırıldığı bir çalışmada evlilik süresiyle evlilik doyumu arasında negatif yönde bir ilişki olduğu sonucuna ulaşılmıştır. Bu çalışmaları destekleyen bir diğer araştırma ise Sancaktar (2016) tarafindan evli çiftlerin evlilik süresine bağlı olarak evlilikte karşılaştıkları problemlere yönelik çözüm becerilerinin, mutluluk (öznel iyi oluş) ve evlilik doyumuna olan etkisinin araştırıldığı çalışmadır. Sözü edilen çalışmada yeni evli çiftlerin evlilik doyumu, uzun süreli evli olan çiftlere göre daha yüksek bulunmuştur. Bunun nedeni olarak, yeni evli çiftlerin evlilik sürelerinin kısa olmasından dolayı ilişkinin daha taze ve yıpranmamış olması, birbirlerine olan sevgilerinin fazla olması ve birlikte bir hayatı paylaşma hevesinin de getirisiyle ilk beş yll gibi bir süreçte evliliklerinden daha fazla doyum alabilmeleriyle ilişkili olabileceği ifade edilmektedir (Çağ, 2011). Uzun süreli evliliklerde ise muhtelif problemlerden dolayı daha fazla yıpranmışlık ve eşler arasında sevgi gösterme davranışlarında azalmaların olması bu çiftlerde evlilik doyumunun daha düşük olmasını açıklamaktadır.

Bu araştırmada evlilik sayısının evlilik doyumu ile ilişkili olmadığı bulunmuştur. Başka bir deyişle, birden fazla evlilik yapan kadınlarla, bir evlilik yapmıs olan kadınların evlilik doyumlarında bir farklılık görülmemektedir. Evlilik iki kişi arasındaki özel bir birlikteliktir ve evlilikte önemli olan eşini tanıyabilme, onunla anlaşabilme ve kaliteli bir birliktelik geçirmektir. Dolayısıyla, kişi ilk kez evlenmiş olsun ya da ikinci veya üçüncü kez evlenmiş olsun evliliğinden hemen hemen aynı beklentilerin karşılanmasını istemektedir. $\mathrm{Bu}$ durumda evlilik sayısının evlilik doyumunu etkilemediği kabul edilebilir bir olgudur. Literatür incelendiğinde de evlilik sayısı ile evlilik doyumu arasındaki ilişki olabileceğini gösteren bir araştırmaya ulaşılamamışır.

$\mathrm{Bu}$ araştırmada eşler arasındaki yaş farkının evlilik doyumu ile ilişkili olmadığı sonucuna ulaşılmıştır. Literatür incelendiğinde daha önce gerçekleştirilen ve eşler arasındaki yaş farkı ile evlilik doyumunun iliş̧kili olmadığını gösteren araştırmalar olduğu görülmektedir. Örneğin, Çağ (2011) tarafından yürütülen bir çalışmada "eşler arasındaki yaş farkı" değişkenine göre evli bireylerin evlilik doyumu düzeyleri arasında manidar fark bulunmamıştır. Benzer şekilde Kendir ve Demirli (2016) ayrıca Kavak (2018) tarafından yürütülen araştırmalarda da eşler arasındaki yaş farkının evlilik doyumunu etkileyen bir olgu olmadığı bulunmuştur. Bu sonuçlar eşler arasında yaş farkı olsa da olmasa da bireylerin evliliklerinden benzer düzeyde doyum alabildiklerini 
göstermektedir. Çünkü evlilikten doyum alabilmek için önemli olan yaş farkı değil, eşlerin anlaşabilme ve iletişim kurabilme becerilerinin olmasıdır (Çăg, 2011). Dolayısıyla eşler arasındaki yaş farkı evlilik doyumunu etkilemeyebilir.

$\mathrm{Bu}$ araştırmada evlilik yaşının bireylerin evliliklerinden aldıkları doyumu etkilemediği sonucuna ulaşılmıştır. Bu bulgu daha önce gerçekleştirilen ve evlilik yaşının evlilik doyumu ile ilişkili olmadığını gösteren araştırma sonuçları ile tutarlılık göstermektedir. Örneğin, Acar (1998) tarafindan yapılan bir araştırmada evlenme yaşının evlilik doyumunu etkilemediği sonucuna ulaşılmıştır. Ayrıca Bahr, Chappell ve Leigh (1983) evlilik yaşı, eş rolü ve evlilik doyumu arasındaki ilişkiyi incelemek için 704 evli çiftle çalıştıkları araştırmada da aynı sonuca ulaşmıştır. Evlenmek için önemli olan biyolojik yaş değil, psikolojik yaştır (Tarhan, 2010) çünkü aynı yaşta olan iki kişiden birinin çocuk karakterli, diğerinin ise olgun bir kişiliğe sahip olması mümkündür. Evlenmek için ise her iki kişinin psikolojik olarak olgunluğa ulaşması, evliliğe hazır olması gerekir (Tarhan, 2010). Dolayısıyla, psikolojik olarak evliliğe hazır olan, evliliği sürdürebilecek olgunluğa sahip olan kişiler genç yaşta da evlenseler ileri yaşta da evlenseler evliliklerinden doyum alabilmektedirler.

Bu araștırmada evlilik doyumuyla ilişkili sosyo-demografik değişkenlerin etkisi kontrol edildiğinde kişiler arası yeterliliğin evlilik doyumunu etkilediği görülmektedir. Başka bir deyişle, kadınların kişiler arası yeterlikleri yüksek olduğunda evliliklerinden aldıkları doyum düzeyleri de yüksek olmaktadır. İnsanlar sahip oldukları iletişim becerileri ile evliliklerini uyumlu ya da uyumsuz boyuta taşıyabilirler ki bu da evlilikten elde edecekleri doyumun ve mutluluğun düzeyini etkileyebilir (Yalçın, 2014). Kişiler arası yeterliliğin ise kişilerin sosyal becerilerinin toplamı olarak nitelendirilen, ilişki başlatma ya da makul olmayan istekleri reddetme, duygusal destek ve çatışma yönetimi şeklinde bir dizi kişiler arası beceriyi içeren psikolojik bir yapı olduğu dikkate alındığında kişiler arası yeterliliği yüksek olan kişilerin evliliklerinde yaşanabilecek çatışmaları çözümlemede, gerektiğinde eşlerine duygusal destek sağlamada daha yeterli olabilecekleri, böylelikle evliliklerinde mutluluğa ve doyuma ulaşabilecekleri düşünülmektedir.

Bu araştırmada iş-aile çatışmasını yönetme öz yetkinliğinin evlilik doyumunu etkilediği görülmektedir. Başka bir deyişle, kadınların iş-aile çatışmasını yönetme öz-yetkinlikleri yüksek olduğunda evliliklerinden aldıkları doyum düzeylerinin de yüksek olduğu bulunmuştur. Bu bulgular, daha önce gerçekleştirilen ve yüksek iş-aile çatışmasını yönetme öz yetkinliğiyle yüksek evlilik doyumunun ilişkili olabileceğini gösteren araştırma sonuçları ile tutarlılık göstermektedir. Örneğin, Hennesssy ve Lent (2008) tarafından yapılan iş-aile çatışmasını yönetme öz yetkinliği ölçeğinin değerlendirme çalışmasında kadınların iş-aile çatışmasını yönetme öz yetkinliği ile evlilik memnuniyeti arasında pozitif ilişki bulunmuştur. Başka bir deyişle, iş-aile çatışmasını yönetme öz yetkinliği daha yüksek olan kişiler, yüksek evlilik doyumu yaşamaktadırlar. Bireylerin iş ve aile rollerine ilişkin çatışmayı yönetebilme yeteneğine olan inançlarının yüksek olması, bu kişilerin iş ve aile rollerinin getirdiği sorumlulukları yerine getirirken daha öz güvenli, problemlerin çözümünde daha yapıcı olabilir. Sonuç olarak bu kişiler evliliklerinde de uyumu, doyumu ve mutluluğu sağlayabilir.

Bu araştırmanın bazı sınırlılıkları bulunmaktadır. İlk olarak bu araştırmada, ilişkisel tarama deseni kullanıldığından bulgulara ilişkin neden-sonuç ilişkisi kurulamaz. İkincisi bu araştırmada iş-aile çatışmasını yönetme öz yetkinliğgi, kişiler arası yeterlilik ve evlilik doyumuna ilişkin bilgiler öz bildirim tarzı ölçekleri aracılığıyla değerlendirilmiştir. Bu nedenle araştırma sonuçları öz bildirim tarzı ölçekleri kullanımından ortaya çıkabilecek sosyal beğenirlik, orta yol cevap verme, katılımcıların duygu durumundan etkilenme gibi tüm sınırlılıkları içermektedir. Üçüncü olarak bu araştırmada, evlilik doyumu tek maddelik bir ölçek kullanılarak değerlendirilmiştir. Ölçek, kapsam ve görünüş geçerliliğine sahip olmasına rağmen ölçeğin diğer psikometrik özelliklerine ilişkin veri bulunmamaktadır. Bu nedenle ilerleyen araştırmalarda çok maddeli ölçekler kullanılarak evlilik doyumu değerlendirilebilir. Son olarak bu araştırmada Ankara, Malatya, Samsun ve Kastamonu illerinde yaşayan çalışan kadınlardan veri toplandığından bulguların, Türkiye'nin farklı bölgelerinde yaşayan kadınlar için genellenebilirliği ve sonuç olarak dış geçerliliği düşüktür.

Sonuç olarak, bu araştırmada kişiler arası yeterlilik ve iş-aile çatışmasını yönetme öz yetkinliğinin evlilik doyumunu yordamakta olduğu bulunmuştur. Kişilerin kişiler arası yeterliliği ve iş-aile çatışmasını yönetme öz yetkinliği yüksek olduğunda evliliklerinden aldıkları doyum düzeyleri de yüksek olmaktadır. Araştırmada evlilik doyumu puanlarının öğrenim düzeyi ve aylık gelir ile düşük düzeyde pozitif yönde ilişkili olduğu saptanmıştır. Yani kişilerin eğitim düzeyi ve aylık gelirleri arttıkça evlilik doyumları da artma eğilimindedir. Ayrıca, görücü usulüyle evlenen, çocuk sayısı fazla olan ve evlilik süresi uzun olan çalışan kadınların evlilik doyumlarının düşük olduğu bulunmuştur. Ancak, çalışan kadınlarda evlilik doyumu evlilik sayısı, eşleri ile aralarındaki yaş farkı ve evlenme yaşları ile ilişkili değildir.

Araştırma sonuçları ve sınırlılıkları dikkate alındığında aşağıdaki önerilerde bulunulabilir:

1. Kişiler arası yeterliliği ve iş-aile çatışmasını yönetme öz yetkinliği zayıf olan kişilerin kişiler arası ilişkilerinde problemler yaşamaları olası olduğundan, iş-aile çatışması yaşamakta olan kadınlara iş-aile çatışmasını yönetme becerilerini geliştirecek eğitimler verilebilir. 
2. Evlilikte yaşanan ve yaşanabilecek sıkıntıları, problemleri olumlu bir şekilde halledebilmek için kişiler arası ilişkileri geliştirme programları ve evlilik öncesi eğitim programları evli ve nişanlı çiftlere uygulanabilir.

3. Bu çalışma sadece çalışan ve evli kadınlarla sınırlı olduğu için gelecek çalışmalarda çiftlerin bu konudaki çalışmalara beraber katılmaları sağlanabilir ve verilecek ilişki geliştirme, çatışma yönetimi ve evlilik öncesi eğitimlerinin çiftler üzerindeki etkileri incelenebilir.

Etik Kurul İzin Bilgisi: Bu araştırma, Ondokuz Mayıs Üniversitesi Sosyal ve Beşerî Bilimler Araştırmaları Etik Kurulunun 02.11.2018 tarihli toplantı 9 2018/287 sayılı kararı ile alınan izinle yürü̈tülmüsstür. 


\section{Kaynakça/References}

Abdel-Khalek, A. M. (2006). Measuring happiness with a single-item scale. Social Behavior and Personality: An International Journal, 34(2), 139-150. doi:10.2224/sbp.2006.34.2.139

Abdel-Khalek, A. M. (2007). Assessment of intrinsic religiosity with a single-item measure in a sample of Arab Muslims. Journal of Muslim Mental Health, 2(2), 211-215. doi:10.1080/15564900701614874

Acar, H. (1998). Ankara'da sosyal hizmet kuruluşlarında çalışan üniversite mezunu evli personelin evlilik doyumu. (Yayımlanmamış yüksek lisans tezi). Hacettepe Üniversitesi, Ankara.

Amanvermez, Y. ve Denizli, S. (2016). İş ve aile çatışmasını yönetme öz-yeterliği ölçeği Türkçe formunun uyarlanması: Yapı geçerliği ve güvenirlik çalışması. Ege Eğitim Dergisi, 17(1), 1-17.

Arslan, M. (2012). İş-aile ve aile-iş çatışmalarının kadın çalışanların iş doyumları üzerindeki etkisi. Birey ve Toplum Dergisi, 2(3), 99-113.

Bahr, S. J., Chappell, C. B., \& Leigh, G. K. (1983). Age at marriage, role enactment, role consensus, and marital satisfaction. Journal of Marriage and Family, 45(4), 795-803. doi:10.2307/351792

Bandura, A. (2012). On the functional properties of perceived self-efficacy revisited. Journal of Management, 38(1), 9-44. doi:10.1177/0149206311410606

Baytemir, K. (2014). Ergenlikte ebeveyn ve akrana bağlanma ile öznel iyi oluş arasındaki iliş̧kide kişiler arası yeterliğin aracıllğ̆. (Yayımlanmamış doktora tezi). Gazi Üniversitesi, Ankara.

Baytemir, K. (2016, Mayıs). Kiş̧iler arası yeterlik ölçeğinin üniversite öğrencileri üzerinde geçerlik ve güvenirlik çalışması. VI. Uluslararası Canik Sempozyumu (Hedefe Doğru Psikolojik Danışma ve Rehberlik Sempozyumu), Ondokuz Mayıs Üniversitesi, Samsun.

Belsky, J. (1990). Children and marriage. In E. D. Fincham, \& T. N. Bradbury (Eds.), The psychology of marriage (pp. 172-200). New York: Guilford Press.

Bradbury, T. N., Fincham, F. D., \& Beach, S. R. (2000). Research on the nature and determinants of marital satisfaction: A decade in review. Journal of Marriage and Family, 62(4), 964-980.

Buhrmester, D., Furman, W., Wittenberg, M. T., \& Reis, H. T. (1988). Five domains of interpersonal competence in peer relationships. Journal of Personality and Social Psychology, 55(6), 991-1008. doi:10.1037/00223514.55.6.991

Buluş, M. ve Bağcı, B. (2016). Evlilik doyumu: Aile yılmazlığı ve etkili iletişim becerilerinin rolü. Mehmet Akif Ersoy Üniversitesi Eğitim Fakültesi Dergisi, 1(40), 136-152.

Byrne, B. M. (2012). Structural equation modeling with Mplus: Basic concepts, applications, and programming. New York: Routledge Academic.

Çağ, P. (2011). Evli bireylerde eş desteği ve evlilik doyumu. (Yayımlanmamış yüksek lisans tezi). Hacettepe Üniversitesi, Ankara.

Çarıkçı, İ. H. ve Çelikkol, Ö. (2009). İş-aile çatışmasının örgütsel bağlılık ve işten ayrılma niyetine etkisi. Süleyman Demirel Üniversitesi Sosyal Bilimler Enstitüsü Dergisi, 1(9), 153-170.

Çelik, M. ve Turunç, Ö. (2009). Aile-iş çatışması, iş stresi ve örgütsel sadakatin iş performansına etkisi: Savunma sektöründe ampirik bir çalışma. Savunma Bilimleri Dergisi, 8(2), 217-245.

Çilli, A., Kaya, N., Bodur, S., Özkan, İ. ve Kucur, R. (2004). Ev kadınlarında ve çalışan evli kadınlarda psikolojik belirtilerin karşılaştırılması. Genel Tup Dergisi, 14(1), 1-5.

DeSalvo, K. B., Fisher, W. P., Tran, K., Bloser, N., Merrill, W., \& Peabody, J. (2006). Assessing measurement properties of two single-item general health measures. Quality of Life Research, 15(2), 191-201. doi:10.1007/s11136-005-0887-2 
Elo, A.-L., Leppänen, A., \& Jahkola, A. (2003). Validity of a single-item measure of stress symptoms. Scandinavian Journal of Work, Environment \& Health, 29(6), 444-451. doi:10.5271/sjweh.752

Finney, S. J., \& DiStefano, C. (2013). Non-normal and categorical data in structural equation modeling. In G. R. Hancock \& O. Mueller (Eds.), Structural equation modeling: A second course (2nd ed., pp. 439-492). Greenwich, CT: Information Age Publishing.

Gorchoff, S., John, O. P., \& Helson, R. (2008). Contextualizing change in marital satisfaction during middle-age: An 18-year longitudinal study. Psychological Science, 19, 1194-1200. doi:10.1111/j.14679280.2008.02222.x

Güngör, Z. Y. (2019). Evli bireylerde yaşam doyumunun yordayıcısı olarak evlilik doyumu ve bağlanma boyutları. (Yayımlanmamış yüksek lisans tezi). Çukurova Üniversitesi, Adana.

Hair, J. F., Black, W. C., Babin, B. J., \& Anderson, R. E. (2014). Multivariate data analysis (7th ed.). Essex: Pearson Education Limited.

Hennessy, K. D. (2005). Work-family conflict self-efficacy: A scale validation study. (Unpublished dissertation). The University of Maryland, Maryland.

Hennessy, K. D., \& Lent, R. W. (2008). Self-efficacy for managing work-family conflict validating the English language version of a Hebrew scale. Journal of Career Assessment 16(3), 370-383. doi: $10.1177 / 1069072708317383$

Houser, A. G. (2009). Evli bireylerin sahip oldukları iletişim çatışması türü, romantik kıskançlık ve duygusal zeka düzeylerinin evlilik doyumuna etkisi. (Yayımlanmamış doktora tezi). Ankara Üniversitesi, Ankara.

Howitt, D., \& Cramer, D. (2014). Research methods in psychology (4th ed.). Harlow: Pearson.

Jamieson, S. (2004). Likert scales: How to (ab) use them. Medical Education, 38(12), 1217-1218. doi:10.1111/j.1365-2929.2004.02012.x

Kahraman, Z. (2011). Bir evlilik ve aile hayatı ĕgitim programının evli kadınlarda evlilik uyumuna ve aile sistemine etkisi. (Yayımlanmamış yüksek lisans tezi). Marmara Üniversitesi, İstanbul.

Kavak, A. (2018). Evli bireylerde çatışma yönetimi ve evlilik doyumu. (Yayımlanmamış yüksek lisans tezi). Hacettepe Üniversitesi, Ankara.

Kendir, M. E. ve Demirli, C. (2016). Evlilik doyumu üzerinde anne baba tutumunun etkisinin incelenmesi. Education Sciences, 11(3), 96-113.

Kılbitmez, R. (2018). Çalışan evli kadınların evlilik doyumu düzeylerinin demografik değişkenler ve ev içi iş paylaşımı üzerinden yordanması. (Yayımlanmamış yüksek lisans tezi). Bahçeşehir Üniversitesi, İstanbul.

Kızılgöl, A. (2012). Kadınların iş gücüne katılımının belirleyicileri: Ekonometrik bir analiz. Doğuş Üniversitesi Dergisi, 13(1), 88-101.

Knapp, T. R. (1990). Treating ordinal scales as interval scales: An attempt to resolve the controversy. Nursing Research, 39(2), 121-123. doi:10.1097/00006199-199003000-00019

Lewis, R. A., \& Spanier, G. B. (1979). Theorizing about the quality and stability of marriage. In W. R. Burr, R. Hill, F. I. Nye, \& I. L. Reiss (Eds.), Contemporary theories about the family (pp. 268-294). New York: The Free Press.

Norman, G. (2010). Likert scales, levels of measurement and the "laws" of statistics. Advances in Health Sciences Education, 15(5), 625-632. doi:10.1007/s10459-010-9222-y

Özgüven, İ. E. (2009). Evlilik ve aile terapisi. Ankara: PDREM Yayınları.

Özgüven, İ. E., Ekici, G., Argun, N. ve Dilek, N. (2014). Evlilik ve aile terapisi. Ankara: Nobel Yayınevi.

Polat, D. (2006). Evli bireylerin evlilik doyumları, aldatma ĕğilimleri ve çatışma ĕgilimleri arasındaki ilişkilerin bazı değişkenler açısından incelenmesi. (Yayımlanmamış yüksek lisans tezi). Ankara Üniversitesi, Ankara. 
Rhemtulla, M., Brosseau-liard, P. É., \& Savalei, V. (2012). When can categorical variables be treated as continuous? A comparison of robust continuous and categorical sem estimation methods under suboptimal conditions. Psychological Methods, 17(3), 354-373. doi:10.1037/a0029315

Robins, R. W., Hendin, H., \& Trzesniewski, K. H. (2001). Measuring global self-esteem: Construct validation of a single-item measure and the Rosenberg self-esteem scale. Personality and Social Psychology Bulletin, 27(2), 151-161. doi:10.1177/0146167201272002

Sancaktar, N. (2016). Yeni evlenen ve uzun süredir evli olan çiftlerin evlilikte problem çözme becerisi düzeylerinin öznel iyi oluş ve evlilik doyumu düzeyleri ile ilişkisinin incelenmesi. (Yayımlanmamış yüksek lisans tezi). Beykent Üniversitesi, İstanbul.

Schlomer, G. L., Bauman, S., \& Card, N. A. (2010). Best practices for missing data management in counseling psychology. Journal of Counseling Psychology, 57(1), 1-10. doi:10.1037/a0018082

Solmuş, T. (2011). Çift, evlilik ve aile terapisi. İstanbul: Doruk Yayınları.

Spanier, G. B., \& Lewis, R. A. (1980). Marital quality: A review of the seventies. Journal of Marriage and the Family, 2(4), 825-839.

Spitzberg, B. H., \& Cupach, W. R. (2012). Handbook of interpersonal competence research. New York: SpringerVerlag.

Şahin, E. E. ve Gizir, C. A. (2013). Kişiler arası yetkinlik ölçeği-kısa formu: Geçerlik ve güvenirlik çalışmaları. Mersin Üniversitesi Ĕ̈itim Fakültesi Dergisi, 9(3), 144-158.

Şen, B. (2009). Evlenmek üzere başvuruda bulunan bir grup nişanlı çiftin evlilik ve 'evlilik öncesi çift eğitimi'ne ilişkin bilgi, görüş ve değerlendirmeleri. (Yayımlanmamış yüksek lisans tezi). Hacettepe Üniversitesi, Ankara.

Tabachnick, B. G., \& Fidell, L. S. (2012). Using multivariate statistics (6th ed.). Boston, MA: Pearson.

Tarhan, N. (2005). Kadın psikolojisi. İstanbul: Nesil Yayınları.

Tarhan, N. (2010). Evlilik psikolojisi. İstanbul: Timaş Yayınları.

Taşköprü, M. (2013). Evlilik doyumu ile problem çözme becerileri, stresle başa çıkma ve evlilik süresi arasındaki ilişkinin incelenmesi. (Yayımlanmamış yüksek lisans tezi). İstanbul Bilim Üniversitesi, İstanbul.

Wanous, J. P., Reichers, A. E., \& Hudy, M. J. (1997). Overall job satisfaction: How good are single-item measures? Journal of Applied Psychology, 82(2), 247-452.

Yalçın, H. (2014). Evlilik uyumu ile sosyodemografik özellikler arasındaki ilişki. Eğitim ve Öğretim Araştırmaları Dergisi, 3(1), 250-261.

Yıldırım, İ. (1993). Farklı sosyo-ekonomik düzeydeki evli bireylerin doyum düzeyleri. Psikolojik Danışma ve Rehberlik Dergisi, 1(4), 23-29. 